Marquette University

e-Publications@Marquette

Spanish Languages and Literatures Research and

Languages, Literatures and Culture Faculty

Publications

Research and Publications

$1-1-2014$

Rio hacia la nada: Hacia la unidad en la poesía de amor de Clara Janés

Anne Pasero

Marquette University, anne.pasero@marquette.edu

Published version. "Rio hacia la nada: Hacia la unidad en la poesia de Clara Janes," in Secretos y verdades en los textos de Clara Janés. Ed. Nadia Mékouar-Hertzberg. Bern: Peter Lang International Academic Publishers, 2014: 143-162. Publisher Link. (C) 2014 Peter Lang International Academic Publishers. Used with permission. 
AnNe M. Pasero, MarquetTe University, Mitwaukee, WI (USA)

\section{Río hacia la nada: Hacia la unidad en la poesía de amor de Clara Janés}

En un período de más de veinticinco años, la gran poeta española Clara Janés demuestra una actitud hacia el amor que es totalmente inclusive y abarca a toda manifestación, en múltiples y diversas dimensiones (erótica, espiritual, mística). Expresa sus sentimientos variados con el mismo espíritu de paz y unión que prevalece en todos sus libros, capaz de fundir diferencias tanto en forma como en tema para llegar a una última totalidad y sentido de armonía trascendente que perdura.

Desde Eros (1981) pasando por Kampa (1986) y luego Creciente fértil (1989) hasta Rosas de Fuego (1996) y ahora Río hacia la nada (2010), desarrolla Janés una trayectoria de expresión hacia el amor que es a la vez multifacética pero también unificadora en su acercamiento. Mientras que Janés nunca se haya querido considerar feminista, sin embargo se enfrenta continuamente a la cuestión de expresión de la mujer, y casi siempre a través del amor, sea de tipo erótico, místico, mítico o espiritual. Para esta expresión, aprovecha Janés de un lenguaje y enfoque más bien típicos de la escritura femenina (écriture féminine), que acentúa la cuestión de diferencia y de pluralidad al mismo tiempo. Mi estudio también dará importancia a este libro más reciente de Janés, Río hacia la nada, en que favorece la poeta una visión hinduista para ayudar a resolver diferencias en la expresión del amor, tanto personal como universal.

Janés es una escritora quien refleja en su vida y obra una pasión por la escritura y belleza de la palabra. En toda su trayectoria literaria desde 1964, ha cultivado todos los géneros: novela, ensayo, relato, biografía y especialmente poesía. También en su labor importante como traductora ha dado a conocer la obra lírica de autores contemporáneos importantes 
como los checos Vladimir Holan y Jaroslav Seifert, igual que poetas turcos y persas tanto modernos como místicos antiguos. Por su labor de traducción y difusión de otras literaturas ha recibido premios importantes a lo largo de su carrera, entre ellos el Premio Nacional de Traducción por el conjunto de su obra (1997). Ha ganado también otros premios literarios a través de los años, con los más recientes siendo el Jaime Gil de Biedma (2002), la Medalla de Mérito Bellas Artes (2004), el Premio Teresa de Avila (2007), el Premio de Poesía Ciudad de Torrevieja (2009) para Río hacia la nada, y en 2011 el I Premio de Poesía Experimental Francisco Pino para Movimientos insomnes.

Publica Janés su primer libro en 1964 (Las estrellas vencidas) y desde 1983 participa también en numerosos encuentros literarios nacionales e internacionales. Su obra ha sido traducida a más de 20 idiomas. De hecho, en esta última década, Janés ha sacado una variedad de publicaciones integradas en la antología poética, Poesía erótica y amorosa (2010), el libro de poesía ya mencionado, Río hacia la nada, y su libro en prosa dedicado a la gran filósofa y amiga, María Zambrano: Desde la sombra llameante (2009). Entre otros libros recientes de poesía se incluyen: La indetenible quietud (2008), Fractales (2005), Vilanos (2004), Los secretos del bosque, (Premio Gil de Biedma) y Paralajes (2002).

Cuando se piensa en la obra de Janés y toda su temática, estilística y estética, el tema que domina siempre es el amor, el amor en sus distintas y variadas fases (espiritual, platónica, erótica, mística), y se manifiesta en sus obras tempranas datando del año 1964 (Las estrellas vencidas) como en las más recientes hasta hoy. El amor ha sido siempre el tema más importante para Janés y se presenta en su obra en muchas facetas innovadoras, que hacen de ella una escritora excepcional y única. Desde el momento que Janés empieza a escribir poesía durante sus años de estudiante, se mueve entre el esencialismo y el existencialismo, siempre dentro del contexto de amor, debatiéndose entre ambos polos hasta llegar a una plena afirmación de la vida. Esta exaltación se sobresale en el libro Vivir (1983), donde cada objeto, obra de creación, ser viviente, paisaje, fenómeno o elemento natural cabe en su poesía, que empieza a manifestar una comunión mística con el cosmos. 
En la antología de 2010, La poesía erótica y amorosa de Clara Janés, se enfoca en los tres libros muy conocidos ya, Eros (1981), Kampa (1986) y Creciente fértil (1989), de generaciones y momentos distintos de la trayectoria literaria de la poeta, y que representan diversos - pero también entrelazados - enfoques en la cuestión del amor. Los tres libros se publican en los años ' 80 pero el de Kampa viene escribiéndose desde bastante antes, y los tres revelan un desarrollo y evolución que marcan la indagación de la poeta en las profundidades del amor y sus múltiples formas de expresión. Dada la importancia de la relación de Janés con Holan, tanto espiritual como literaria, es apropiado que la antología se abra con poemas de Kampa (isla checa donde se refugió Holan) y que sean seguidos por los de Eros y Creciente fértil, que evidencian un movimiento hacia lo erótico pasando por lo místico y espiritual. Como afirman los editores de la antología en la cubierta: "El erotismo de Clara Janés es un erotismo que no desdeña, antes busca la conexión con lo espiritual: en estos versos el amor es un vehículo hacia algo más alto sin dejar de ser puro goce y sensualidad él mismo."

Los poemas reunidos en la antología antedicha son introducidos por un comentario de la gran filósofa y amiga de Janés, María Zambrano, en "La voz abismática," publicado originalmente en 1986. Dice Zambrano, hablando de la voz poética de Janés: "La de Kampa es la voz del peregrino por amor, del caballero solitario que toda su vida ha soñado un amor y ha ido hacia él, paso a paso corriendo riesgos, la muerte dando un sangre a su tiempo, y por fin le encuentra" (III). La gran hispanista ya jubilada, Biruté Ciplijauskaité, quien ha estudiado la obra de Janés con profundidad, también afirma la importancia de su voz poética y especialmente para el tema del amor: "En cuanto al amor, Clara Janés es probablemente la poeta que más fases distintas representa: desde la actitud femenina tradicional, pasando por asomos de lo místico y lo platónico, hasta la culminación erótica. Creciente fértil sigue siendo probablemente el libro más logrado en este campo" ("Medusa" 93). Estas fases son las que se ven desarrolladas poéticamente en los tres libros reunidos en la antología.

Y por supuesto, cuando se habla de la presentación del amor en la poética de Janés, hay que hablar de la importancia de la figura del poeta checo, Vladimir Holan, no sólo por su obra sino también por su 
espíritu. A Holan le conoce Janés por primera vez a través de su obra, Una noche con Hamlet, que le llegó a sus manos justo en un momento muy necesitado, cuando todavía sufría de la muerte de su padre y de un estancamiento poético subsiguiente, entre 1970-1971. Como ya es bien sabido, la obra de Holan le ha servido a Janés como fuente de inspiración y de resurrección personal, para que vuelva a la vida, tanto espiritual como poética. Esta relación con Holan tendrá resonancia en toda su obra desde entonces. Como dice la poeta cordobesa Juana Castro: "La relación amorosa, mística de Vladimir Holan y de Clara Janés es uno de los más hermosos dones a la palabra del poeta checo ... Kampa es un gran libro de amor" (presentación 3). Holan resulta ser el Hamlet y también Orfeo que necesita Janés para volverse a la vida y a la escritura, una y la misma cosa, y para llegar a ser esa Ofelia que ya no se "adentraba en las aguas" sino que, como "Eurídice, rescatada de los infiernos, contemplaba la primera estrella de la tarde" ( La voz 105).

Rosa Chacel también, la gran escritora y muy amiga de Janés, comentó en la lectura poética de Kampa en el Ateneo hace muchos años (1978) que con la poeta se encuentra una verdadera voz de amor dedicada en este momento a su maestro Holan, que luego será transmitida a través de toda su obra posterior y especialmente en los libros de poesía ya indicados: "Kampa, dedicado al poeta Vladimir Holan, largo poema de amor al Maestro: más que homenaje profesión de fe” (99).

La relación de Janés con Holan no queda sólo en lo literario, sino que se extiende a todo su ámbito poético, personal y espiritual; ella se dedica a aprender el propio lenguaje del maestro y a viajar hasta verle en cuatro ocasiones distintas $(1975,1977,1978,1979)$, llevando consigo poesías suyas y regalos del mar como ofrendas para él. En $\mathrm{La} \mathrm{voz}$ de Ofelia, libro autobiográfico de prosa poética que salió en 2005 pero que estuvo 12 años en preparación, se centra Janés en la importancia de esta relación con Holan, literaria y personal, tanto para su trayectoria poética como para su desarrollo psíquico y espiritual. En él, la poeta se convierte en su propia Ofelia con su propia voz, en búsqueda de su Hamlet personal (y/u Orfeo) quien le guíe y le lleve hasta la salvación (epifanía), hasta su "gruta de las palabras," como se refiere Janés a todo el ámbito simbólico-poético de Holan. En una conferencia 
que presentó Janés en París (2006), habla ella de la sincronicidad entre ella y Holan:

Sus temas eran mis temas: el dolor, el sufrimiento humano, el límite, la fugacidad ...; su manera de expresarlos tan atractiva, por la fuerza de sus imágenes y su modo de emplear la sorpresa al final del verso, que me arrastraba. La impresión que me causaron sus poemas fue tan honda que me hizo volver a la poesía pensando en un solo lector que pudiera recibir los míos como yo recibía los suyos (3).

Kampa, escrito entre 1975 y 1979 pero no publicado hasta 1986, está dividido en cuatro partes, o ciclos, y se enfoca casi entero en la relación poética, espiritual e intelectual con Holan y va dedicado a él. Como ya se ha indicado, Kampa es la isla en el centro de Praga donde residía Holan en su estado de recluso. En muchas maneras, la obra de Janés representa un poema de amor tradicional hacia el que ha inspirado su resurgimiento poético y su vuelta a la escritura. Y, va íntimamente relacionado con el renacimiento de la voz poética de Janés después de muchos años de estancamiento creativo. Janés misma dice "el encuentro con Holan tiene un carácter de resurrección" (conferencia, Paris 13). Y según la hispanista Sharon Ugalde, "Kampa da testimonio de una resurrección, ese salir del no ser a través del amor nacido en la palabra poética" (Conversaciones 40).

La Parte II de Kampa representa un tipo de obra única en sí-sus versos van acompañados por canto, que Janés misma ha compuesto. En la conferencia de París, ella se refiere al origen de este canto, justo después de la vuelta de Praga: “... una noche estaba fregando los platos y me puse a cantar, ante todo murmurando sílabas, rompiendo palabras. Lo que salió es la segunda parte de Kampa, que es un canto de carácter místico, como un vuelo, de una levedad análoga a la de la flor del almendro ..." (17). Esta sección de nueve páginas (cinco cantos) significa una expresión de la alegría que llega con la fusión de un ser (el de Janés) con otro (el de Holan), simbólicamente. Sobre todo, esta parte constituye la culminación del proceso de integrar una voz con otra, de esa unión vital y dinámica que resulta del encuentro Janés-Holan. 
En la última visita de Janés a Holan, que coincide en el concluir de Kampa y el presentimiento de la próxima muerte de Holan, es cuando se le entrega a Janés la copia de "Una noche con Ofelia," ese largo poema escrito en 1972 y hasta entonces desconocido por la poeta. Es aquí donde se presenta a una protagonista idéntica a la poeta catalana, una "Ofelia de Barcelona," quien tendría que haber sido completamente intuida y adivinada por Holan. Llegan a tal punto las coincidencias que pocos meses después muere Holan y se ha dado a luz a esta nueva Ofelia que llevará adelante la continuación de la historia iniciada por él, pero complementada y completada por ella un su nueva voz totalmente propia y original. Esta revisión es trascendente para Janés, cuyo ser renacido resulta en una entidad autónoma femenina en todo sentido. A través de su relación poética y textual con Holan, Janés llega a la definición de su "ser de poeta," su encarnación de Orfeo, que me "sacaba de los infiernos ... y abría los límites haciendo que mi libertad se desplegara" (La voz 18).

Eros, publicado en 1981, también ofrece toda faceta del sentir amoroso, pero siempre con un tono mítico y transparente. En este libro, Janés se muestra cándida, directa y explícita en cuanto a su propio erotismo. Se regocija en la libertad de expresar sus instintos sensuales abiertamente. Tal liberación se ha conseguido gradualmente, a través de un trascender de barreras y una creación poética de un paisaje abierto y erótico. Como una de las grandes poetas de amor, Janés manifiesta en Eros todo aspecto de su erotismo, desde la experiencia más sublime hasta la que es descaradamente sexual. El poema introductorio, "Eros," ofrece la clave a la orientación de la obra: Janés, quien afirma abiertamente que "amarse al otro es amarse a si" (9), y se exalta en la gratificación erótica. A través de toda la obra, el enfoque de la poeta está en el placer sexual y el descubrimiento erótico, elaborado en términos específicos sexuales.

Ocho años después publicó Janés Creciente fértil en 1989. En su totalidad, este libro afirma el placer de la satisfacción erótica hacia la cual aspira Janés en toda su búsqueda poética. Los dioses que se exaltan son femeninos, recreados de otro tiempo y lugar - reinas de las civilizaciones antiguas de Sumeria, Babilonia e Hitita - y transportadas 
al momento presente. Son mujeres míticas que vuelven a crear las experiencias más eróticas y primordiales. Por ejemplo, en una ocasión, Janés se presenta a sí como Ishtar, la diosa babilónica y asiria del amor y de la fertilidad. "Creciente fértil" es una referencia metafórica al Creciente Fértil de la Antigüedad y también a todo el cuerpo femenino y más específicamente al útero. También sugiere el país de Turquía, cuya bandera lleva la luna creciente y así reestablece la conexión entre el lugar geográfico y el deseo femenino. A través de toda la obra, como en sus libros anteriores de poesía, las referencias a tierras exóticas corresponden a la expresión del deseo erótico desinhibido. En esta obra tan única, Janés habla por y para la mujer, creando una dimensión mítica y universal en el tiempo y espacio. El libro más agresivamente erótico de sus obras hasta ahora, Creciente fértil representa lo que describe Janés como una progresión en su búsqueda para una forma específicamente femenina. Esta forma refleja la capacidad de la poeta de cantar en homenaje al ser femenino, firme ahora en su esencia.

Mediante la presentación de diversas formas míticas, consigue Janés que la protagonista se presente como una figura cuyo poder creativo se dirige hacia la expresión de sueños y deseos anteriormente sumergidos. En Creciente fértil, ocupa la figura de Ishtar un lugar central en el mundo poético-mítico que presenta el libro. La diosa asiria y babilonia del amor y de la fertilidad se desdobla en su identidad sumeria, Inanna, reina de la tierra y el cielo. En el mismo prefacio a su obra, Janés se describe a sí misma como habiendo asumido la identidad de las dos: "Yo era Ishtar descendiendo a la orilla del mar a saciar mi deseo. Yo era Inanna, esposa de Dumuzi ..." (13). Con referencia a las dos, evoca la mitología colectiva que representan. Janés, en su elaboración y revisión de esta mitología, con la figura de Ishtar/Inanna como pre-eminente, presenta a la diosa en sus múltiples facetas como una afirmación vigorosa del poder creativo femenino, benéfico e independiente. $\mathrm{La}$ intención de Janés en Creciente fértil es crear una vida autónoma para las entidades femeninas que reelabora, cuya esencia tiene su origen en la fuente original pero que se vuelve completamente única y propia con la versión de la poeta. Lo que consigue Janés por exaltar y deificar a Inanna es devolverle unas cualidades primordiales que han sido por 
mucho tiempo ignoradas, resucitar a una diosa por atributos no solo innatamente positivos pero finalmente autovitalizadores.

En un estudio de la poesía de varias mujeres poetas españolas contemporáneas, Ugalde se refiere a la objetivación del "yo" femenino que tiene lugar en la obra reciente de Janés: "Cuando la poesía de Janés se objetiviza, a partir de Vivir (1986), y disminuye la expresión directa del yo, no significa sumisión, sino el descubrimiento de una entidad femenina autónoma que se manifiesta de distintas formas: la incorporación de la anatomía y el placer erótico femeninos en el texto ... la relación entre la sexualidad femenina y la creatividad poética ..." ("La sujetividad" 519). En Creciente fértil, Janés consigue esa distancia poética y personal a través del mito, llevando al "yo" a un nivel completamente alejado en el tiempo y el espacio, cuya atracción llega a ser no solo individual sino también universal. A través de toda la obra, Janés aprovecha las figuras míticas más importantes para reafirmar el lugar e importancia de la esencia femenina y su erotismo explícito.

En otro libro más reciente, Rosas de fuego (1996), empezado mucho antes pero interrumpido de un tirón por Creciente fértil, Janés sigue su exploración de las dimensiones de amor pero esta vez a través de la pura perspectiva mística. En Rosas, Janés llega a explorar un estado místico que lleva muchos paralelos con el famoso poeta y religioso del Siglo XVI, San Juan de la Cruz, a la vez que crea su forma singular de describir la inmensa sensación de amor que le engolfa. Es interesante que desde el punto de vista contemporáneo, la perspectiva del Siglo $\mathrm{XX}$, Janés termine reflejando una visión parecida a la de San Juan pero que también es única para ella como mujer. Igual que él, aprovecha imágenes de la naturaleza e imágenes eróticas para acabar revelando un estado de intensa espiritualidad, pero conservando siempre su propia voz femenina.

La presentación del amor en términos místicos representa para Janés una auténtica vía de expresión, no solo en toda su dimensión espiritual pero también para ella como mujer. Para ella el misticismo constituye una de las posibilidades femeninas más fértiles de expresión y, como elabora la crítica francesa Luce Irigaray, deja lugar a que la mujer se libere de las restricciones que se le han impuesto y que se 
entregue libremente a una fusión con el "otro" (Moi 136-137). Le ofrece la oportunidad de afirmarse plenamente en el momento de éxtasis y de entregarse al "fuego" de amor, que en este libro simboliza el momento de máxima iluminación, de salirse de sí para perderse en el otro, un instante de completa negación que para Janés, como poeta "mística" y mujer, se convierte en pura afirmación. En su ensayo sobre las "huellas de mujer" en la obra de Janés (204), Ugalde hace referencia a esta relación, subrayando la implícita conexión entre el misticismo y la voz de la mujer, refiriéndose a Irigaray y aludiendo a la inevitable afinidad entre el movimiento espiritual del Siglo XVI y la expresión femenina del siglo contemporáneo.

En el momento climáctico del proceso de amor al final del libro, dedica Janés las últimas poesías a la pura exaltación del placer místico unitivo, y aprovecha para transmitirlo imágenes que convalidan la identidad de la poeta ya transformada en otra y en armonía con la culminación del éxtasis sexual:

Mi ser en sombra, sometido a mansedumbre, brilla, que toda sombra ya hacia el Ser regresa.

Los ojos del amado me contemplan. (48)

Igual que en San Juan, ninguna distracción interrumpe en la escena de amor:

Ni un vencejo distrae
el incesante dar y recibir
en el vacío de la luz,
túnica que desnuda
de lastre los sentidos. (51)

Termina la trayectoria del alma al encontrarse con las "rosas de fuego," símbolo de pureza, pasión y purificación a la vez, y que le deja ya descansar en completa paz y serenidad (51). La última poesía del libro, que arranca de un ingenioso juego de palabras, indica hasta qué punto es consumada la transformación de dos en uno. En la figura del amado se asimilan todos los cuatro elementos en la conversión final: 
Oculto amado,

agua de lluvia,

aliento que mi tierra vivifica,

fuego y aura

desbordando en mis gestos,

nada más necesito,

teofanía es ya mi transparencia.

Clara, Clara es mi nombre,

cada dia crece mi amor. (52)

En Rio hacia la nada, logra Janés unir los mismos conceptos míticos y místicos que desarrolla en libros anteriores, de tal manera que la visión de la mujer que se presenta aquí es una que es constantemente unida y unificadora, entera en su totalidad y armonía. Janés emplea tanto imágenes eróticas como lenguaje místico tradicional para llegar a esta presentación, que se solidifica en este libro reciente. El hinduismo por su mera naturaleza es unificadora, y refleja múltiples visiones y barreras. Para Janés el hinduismo llega a ser la manera en que la poeta pueda unir todas las distintas expresiones de amor que se han desarrollado en su obra. Cito aquí del profesor y traductor Louis Bourne, que ha traducido varios de los poemas de este libro, entre otros libros de Janés:

El poemario de Clara Janés a menudo alude a estos dos conceptos fundamentales del hinduismo, la búsqueda deseante del individuo de su vínculo eterno con una ida monista del universo. Las huellas que resbalan y caen "en el primordial silencio" aproximan la contemplación, la búsqueda de la persona interior que conecta con la unidad fundacional (87).

Y luego afirma: "Clara Janés se empapa del hinduismo para hacer una ruta analógica pero imaginativa e independiente en la búsqueda de aclarar su propia espiritualidad"(7).

Como dice Madhu Khanna en su artículo "A Conversation on Two Faces of Hinduism and their Implication for Gender Discourse," "Hinduism is not a religion of one book or a single prophet, but a process, a way of life where competing claims have found an honourable place... The word 'Hindu' has fairly fluid boundaries ... ("El hinduismo no es una religión de un solo libro o profeta sino un proceso, una forma de vivir donde exigencias contrarias encuentran un lugar de honor ... La 
palabra 'Hindu' tiene fronteras bastante fluidas ..." 81). Aquí volvemos a pensar en Cixous e Irigaray de nuevo. Confirma lo mismo Susana Avila en su Mitología de la India en que dice: "La unidad del hinduismo no es la de un credo invariable sino la unidad de una vida en continuo cambio" y "la salvación está en disipar la ilusión del Yo y del Tú y fundir todo en la Divina Unidad ... (12). Y, el hombre debería "alcanzar la conciencia de que puede sumergirse en el Absoluto desprendiéndose de su individualidad al igual que los ríos pierden su nombre y forma cuando se lanzan al océano ..." (12). Y Mircea Eliade, en su libro Erotismo místico en la India, habla de la experiencia sexual erótica como “iidentidad del gozo,' en la experiencia inexpresable de la Unidad (samarasa), cuando se alcanza el estado de sahaja, del no-condicionamiento, de la espontaneidad pura" (20). Y luego afirma: "sea el que sea el nivel al que se realiza, la conjunción de los opuestos representa la superación del mundo fenoménico, la abolición de toda experiencia de dualidad" (23).

Para Janés en este libro reciente, el río de la vida lleva hacia un destino final desolador, ese de la nada, pero aquí convertido en la vida renovada y trascendente, una luz acogedora que se extiende más allá de todas las barreras, una luz que abre caminos hacia la eternidad:

abre vías al silencio

y multiplica

la inmensidad del río

invitando

al lugar

donde es unidad la nada. (13)

Afirma que de nuevo no hay muerte sino más bien una luz que espera:

Aquí no hay muerte,

sólo luz,

luz de acogida,

luz más allá de la luz (13).

En la muerte, uno está inmerso en el río y llega a ser uno, reunido con todos los elementos de la vida, sumergido en la última armonía donde el ser finito es transformado en un Ser eterno: "Y el ser del río 
entra en su ser,y en su plenitud es ya ser con el Ser"(11). Tranquilidad en el momento de la muerte es resonante con una metamorfosis luminosa:

\author{
y esa calma de muerte \\ indica \\ gloriosa \\ metamorfosis. (11)
}

En otro poema, Janés subraya la fusión de todos los elementos, agua, luz, y palabra, la palabra siendo lo que transciende y transforma memoria material en amor eterno desde antes del Ser, así haciendo crecer tanto la tierra como el corazón humano con elementos del universo (árboles, estrellas). Durante la oscuridad de la noche ("mar de la noche" 35 ) toda diferencia está eliminada-las gotas individuales ya no se distinguen porque llegan a ser parte de una totalidad más grande: "no hay gotas/sino sólo mar" 36). Las palabras, eternamente duraderas, huyen para llegar a ser una con el "aura virginal" (35).

En el poema 17, Janés se dirige al tema de amor específicamente, como parte integral de la vida renovada desde la oscuridad más profunda ("La voz de la vida/que quiere nacer" 39), y como unificador y regenerativo también, y que logra al final una última armonía:

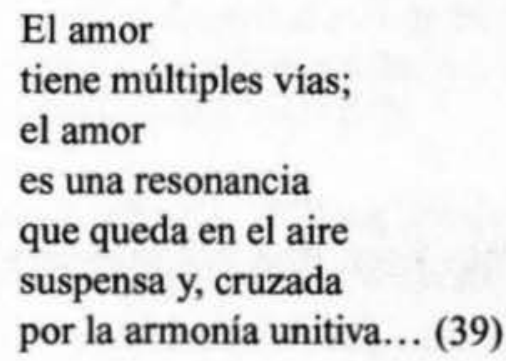

El amor constituye el significado de y para la vida, y para la muerte también, porque trasciende límites y abole diferencias. Janés afirma que el aceptar amor es una forma de renacimiento:

Y el puro contemplar es amar.

$\mathrm{Y}$ el puro reconocer el ser

es albergarlo, 
entrañarlo,

engendrar con él,

estar con él en el centro... (67)

Amor es ser renacido y ese deseo se expresa en palabras que van buscando la armonía del universo (63).

Es un amor trascendente que reside a la vez dentro de uno y fuera, como parte integral del cosmos y universo. Por eso cuando habla Janés, se dirige no sólo a sí pero también hacia esa entidad que está latente fuera, o sea un dios (o una diosa) o una representación de ese otro que existe fuera del ser pero que forma parte esencial de él al mismo tiempo. Y se dirige directamente al amor a veces (67), y otras veces a un tú que no va expresamente definido pero que se puede suponer que refleje tanto al alma del yo como su representación en el mundo exterior. Desde el primer poema, evoca a esta esencia que está continuamente presente e inmutable, y en espera de su transformación: "Estarás con los ojos fijos/en el fondo del agua/a la espera de un indicio ..." (7). Más adelante Janés se refiere a ese espíritu de amor y su poder de transformarlo todo, en oro, en luz, que va abarcando todo lo que rodea (23). Es la misma esencia que convierte lo temporal en permanente, la nada en un nada que "se diluye" en una sustancia mucho más duradera y trascendente:

Tú eres la lisa superficie de la inmovilidad donde las huellas resbalan, caen en el primordial silencio. (27)

Varias veces hace eco del don espiritual que nace desde el "fondo del agua" (33) y que será nutrido y absorbido por el ser con constante evolución con las fuerzas de la naturaleza. Se convertirá en esencia (nube) que transforma al propio ser:

\footnotetext{
Y la nube se hará cargo de tu ser; y de la nube pasarás al aire y serás el aliento que insufla tu propio aliento más allá de los confines. (33)
} 
Una vez más se encarama a ese "tú," equiparando "renacer, amor y deseo" (63), y esta relación se lleva a su reafirmación en un poema final en que subraya Janés lo latente del amor y su esencialidad para el ser:

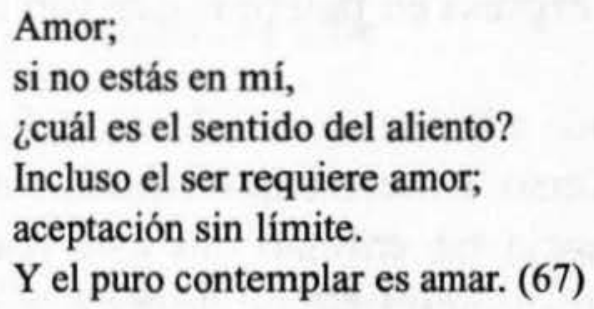

Seguir siendo sin seguir amando es imposible y solo puede ser reencendido por elementos de luz y fuego en constante renovación. Es fuego que irradia por las aguas del río: "Irradia el corazón/para que nazca el fuego" (31). El fuego es eterno, con vuelta para su origen hacia dos mil años:

ese fuego sagrado tenaz

a la orilla del agua,

que a más de dos mil años

se remonta. (47)

Es el fuego de sacrificio y rejuvenecimiento, vida y muerte a la vez, pasado y futuro simbolizados tanto en humo como ceniza: "Se va en humo el futuro/y en ceniza se amontona el pasado" (51). Y aunque el fuego esté apagado, se enciende de nuevo para guiar e iluminar la oscuridad que sigue a la muerte:
hay que seguir
ahondando en la noche
hasta el profundo centro
para entrar en el giro. (61)

Es un río sin fin, bañado en sombras iluminadas por la pasión de ser ("enardece el puro ser" 57), que ilumina la senda hacia el momento final de consumación y totalidad:

y el amanecer del sol, que desnuda 
de sentido el deseo

al mezclarse llameante

con la ablución matutina. (56)

Se expande el universo, se multiplican los instantes y se unen en uno; queda una voz solitaria para esperar el momento final de descanso y resurrección: "y únicamente una voz,/un mantra,/indica el estar en vela" (66). Luego continúa esa voz: "mantente ajeno, en calma,/que nunca, nunca, nunca/volverás a andar sobre las aguas" (66). Y en el poema final, Janés reitera que las aguas del olvido, mientras habiendo olvidado su ser inicial, preservan su esencia última ("no recuerda su forma inicial/pero conserva el ser" (69). Como en San Juan y su Cántico espiritual, en el mismo espíritu místico como antes, todos los sentidos humanos son callados y apaciguados, en anticipo de esa luz final y eterna:

Y el tacto, el ojo, y el oído

cedan al abandono,

un no saber que espera la luz

desde la mansedumbre. (70)

De mucha importancia también es la figura de la diosa hindú, quién reúne en sí todas las fuerzas unificadoras de la naturaleza. Afirma Janés:

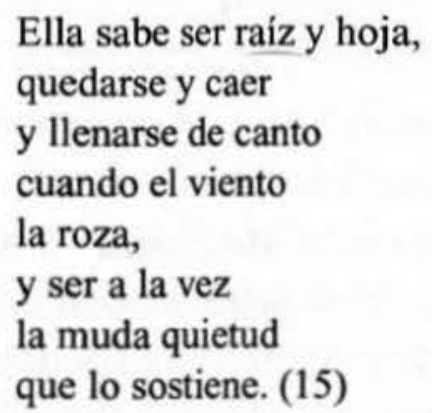

Como subraya Carol Christ, la simbología de la diosa es importante porque subraya el poder y legitimidad de la mujer en todo sentido: "The symbol of the Goddess is the acknowledgement of the legitimacy of female power as a beneficent and independent power ("El símbolo de la Diosa es el reconocimiento de la legitimidad del poder femenino como un poder benéfico e independiente" 367). La diosa de Janés tiene el 
poder no sólo de animarse a sí misma pero también a todas las fuentes y naturalezas que le rodean y le infunden. Es a la vez fuerza, ánima y tranquilidad. A través de ella, adquiere uno el poder no sólo de seguir viviendo pero también de poder trascender esa experiencia individual para llevarla a una dimensión mucho más universal:

Vivir es seguir,
seguir respirando
hasta convertirse en el susurro
del espiritu del bosque... (15-16)

La diosa es la que da vida a todo, la que tiene el poder de crear desde la nada, de dar forma y luz a los elementos inanimados y latentes, y que llena de paz y alegría a su alrededor espiritual:

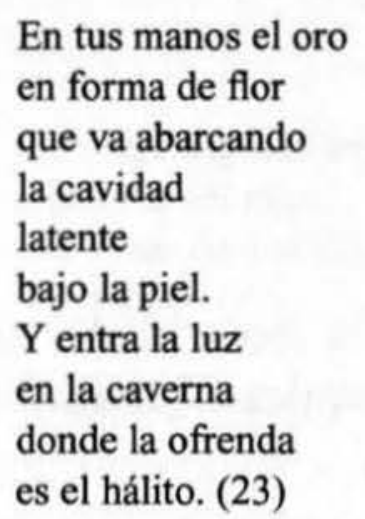

Como dicen los autores Cleary y Aziz en Twilight Goddess, muchas veces la diosa se presenta como una figura maternal universal, que cuida y nutre a la vez, como se ve en Río también. Esta figura es identificada con todo esto: "identified with the creative principle, and also with existence itself, she gives life and grants boons. In the process she is giving of herself, in traditional visions, for she is also life itself and she is Being itself ("identificada con el principio creativo, y también con la existencia en sí, de vida en sí y otorga regalos. En el proceso da de sí misma, en visiones tradicionales, porque también es la Vida y el Ser en si"9).

En el mundo regido por la diosa, tienen papel esencial los cuatro elementos a los cuales hemos aludido antes. Especialmente figuran 
fuego y agua como primordiales pero también tienen su función esencial el aire y la tierra. Fuego y agua se funden en un constante movimiento y transformación: "Irradia el corazón/para que nazca el fuego/que vaga sobre las aguas" (31). Es la llama sobre el agua que invoca a despertar, a renacer y arrancar para volar otra vez. Y es el agua, como sugiere el título, que nos lleva en su constante fluir sin fin, hacia la nada, hacia el fuego del sacrificio, ese "fuego sagrado tenaz,/a la orilla del agua" (47), que a la vez que destruye también da vida y esperanza de amor (53). Mientras el fuego de la vida se consuma, enfatiza la poeta que "hay que seguir/ahondando/ahondando" (61) para llegar hasta el puro centro de la esencia de la inexistencia. Al final, "en el borde de la noche" a la orilla del río, sólo el amor espera para ser resucitado: "y únicamente una voz/ un mantra/indica el estar en vela" (65). Amor y ser son uno y lo mismo, lo que perdura a través del tiempo y por encima de la muerte. Termina Janés su poemario con ansia de esperanza, cuando todos los elementos se hayan fundido en una transformación que "no recuerda su forma inicial/pero que conserva su ser" y una memoria de "un mandala que no ocupa lugar pero que anida en el corazón"(69). Todas las aguas de la lluvia y del río convergen al final en un "mar de significados" (69), empujando hasta una cesión y un último abandono de "autodominio, compasión y caridad" (69), dónde sólo queda "un no saber que espera la luz/desde la mansedumbre" (70).

Hemos visto cómo la larga trayectoria poética de Janés, desde su libro inicial Las estrellas vencidas, llegando hasta el momento presente con Río hacia la nada, enfoca al amor desde una perspectiva dinámica pero constante, cada vez con mayor vehemencia y transformación, destacando ese proceso que al principio se ve como tentativo e incluso a veces negativo (búsqueda anhelante de la identidad del ser) pero que al final se vuelve en completa afirmación - del yo, del otro, y de la relación entre sí. Destaca Mariarosa Scaramuzza la importancia para Janés de este libro: "De hecho, la ocasión del viaje a la India de Janés ha significado para ella un recuperar y profundizar en sus núcleos temáticos fundamentales, como la noche, en que el sueño humano deposita la posibilidad de una nueva aurora" (60). Esta misma evolución se ve claramente en la presentación de la antología erótica y amorosa, que se 
abre con Kampa y el famoso poema de "Amor" hacia Holan, que expresa su deseo apasionado de una relación con él aunque sea sólo verbal ("aunque sea en palabras/y sin saber quién soy/una vez me has mirado" 18) hasta la pura exaltación erótica, llevada a cabo en el último poema de Creciente fértil:

Todo es oscuridad, un fluir de oro entre las piernas y un cóncavo abandono a sus halagos, mientras aún erecta la torre en mí sumida vuelve a soltar su desbandada de cometas. (52)

(Nota de autora: Las traducciones del inglés son mías. Algunas ideas aludidas aquí en la introducción son desarrolladas mucho más en mi estudio y traducción, Ophelia's Voice (La voz de Ofelia), New Orleans: University Press of the South, 2011).

\section{Obras citadas}

Avila, Susana. Mitología de la India Mítica y Mística. Madrid: Miraguano, 1999. Impreso.

Bourne, Louis. "Indagando en la poesía contemplativa de Clara Janés: La perspectiva de su traductor." Cuadernos de ALDEEU 23 (otoño 2011): 85-96, Impreso.

Castro, Juana. "Presentación de Clara Janés.” Córdoba, 16 abril 2005: 3. Sin publicar.

Chacel, Rosa. "Dos palabras" (Presentación de Kampa, 1978). Kampa. Madrid: Hiperión, 1986: 98-101. Impreso.

Christ, Carol P. "Why Women Need the Goddess: Phenomenological, Psychological, and Political Reflections." Christ and Judith Plaskow. Womanspirit Rising: A Feminist Reader in Religions. NY: Harper Collins, 1992. 273-285. Rpt. Heresies, Spring 1979. Impreso. 
Ciplijauskaité, Biruté. "De Medusa a Melusina: recuperación de lo mágico." La Chispa '97: Selected Proceedings (1997): 91-99. Impreso.

Cleary, Thomas y Sartaz Asiz. Twilight Goddess: Spiritual Feminism and Feminist Spirituality. Boston and London: Shambhala, 2009. Impreso.

Eliade, Mircea. "Sobre la erótica mística." Erotismo místico en la India. Barcelona: Kampa 2001. 13-24. Impreso.

Holan, Vladimir. "Una noche con Ofelia.”Trad. Clara Janés. Pamplona: Pasajes 3 (1985): 59-63. Impreso.

Janés, Clara. Las estrellas vencidas. Madrid: Agora, 1964. Impreso.

-. Eros. Madrid: Hiperión, 1981. Impreso.

-.Vivir. Madrid: Hiperión, 1983. Impreso

- Kampa. Madrid: Hiperión, 1986. Impreso.

—. Creciente fértil. Madrid: Hiperión, 1989. Impreso.

-. Jardin y laberinto. Madrid: Debate, 1990. Impreso.

-. Rosas de fuego. Madrid: Cátedra, 1996. Impreso.

-. Los secretos del bosque. Madrid: Visor, 2002. Impreso.

-. Paralajes. Barcelona: Tusquets, 2002. Impreso.

-.Vilanos. Madrid: AdamaRamada, 2004. Impreso.

- Fractales. Valencia, España: Pre-textos, 2005. Impreso.

-. La gruta de las palabras. Oviedo: Universidad de Oviedo, 2005. Impreso.

-. La voz de Ofelia. Madrid: Siruela, 2005. Impreso.

—. "Conferencia." París, 2006: 1-22. Sin publicar.

-. La indetenible quietud. Madrid: Siruela, 2008. Impreso.

-. María Zambrano: Desde la sombra llameante. Madrid: Siruela, 2010. Impreso.

-. Poesía erótica y amorosa. Barcelona y México: Vaso Roto, 2010. Impreso.

-. Río hacia la nada. Barcelona: Plaza y Janés, 2010. Impreso.

Khanna, Madhu. "A Conversation on Two Faces of Hinduism and their Implication for Gender Discourse." Women's Voices in World Religions. Ed. Haker, Hille, Susan Ross and Marie-Therese Wacker. London: SCM Press, 2006. 81-89. Impreso. 
Moi, Toril. Sexual/Textual Politics: Feminist Literary Theory. London and NY: Methuen, 1985. Impreso.

Scaramuzza Vidoni, Mariarosa. Compás de códigos en la poesía de Clara Janés. Madrid: Devenir, 2012. Impreso.

Ugalde, Sharon Keefe. "La sujetividad desde 'lo otro' en la poesía de María Sanz, María Victoria Atencia y Clara Janés.” Revista Canadiense de Estudios hispánicos XIV.3 (primavera 1990): 511-23. Impreso.

-. "Conversación con Clara Janés." Conversaciones y poemas. Madrid: Siglo XXI de España, 1991. 39-53. Impreso.

—. "Huellas de mujer en la poesía de Clara Janés." Anales de la Literatura Española Contemporánea 18 (1993): 193-209. Impreso.

Zambrano, María. "La voz abismática." Diario 16 (7 dic. 1986): III. Impreso. 